\title{
1. The relevance of theory and history: the essence and origins of international law
}

\author{
Alexander Orakhelashvili
}

\section{LAW AND SCHOLARSHIP}

The international legal argument focuses on the analysis of legal rules and instruments, identification of their content and the rules and instruments' application to facts. The ultimate aim of studying international legal theory is to understand the principal systemic and structural categories of the international legal system - those which account for the creation and operation of particular rules of international law. Theory also provides a starting-point for studying international law in an inter-disciplinary perspective, analysing its interaction with ethics, morality, politics, culture and economy, including factors that influence the choice of States to accept or reject a particular rule of international law, or decisions whether or not to comply with rules that they have accepted. These considerations cannot, however, replace the basis of validity of the rules in question. To remain a valid exercise in international legal argument, theory has to tangibly relate to - indeed, prioritise - principal categories through which the international legal system operates in terms of creation, implementation and modification of international legal rules. Consequently, one of the principal tasks of theoretical analysis is to separate that part of theory which accurately reflects the nature and content of international law from that which merely constitutes a product of theoretical conjecture and of over-theorising.

Over-theorising has a significant history. As Onuf has explained, in the nineteenth century 'the legal order was all the scholar saw around him, for it was an order of his own making, an artifactual order'. ${ }^{1}$ As WE Hall observed at the end of the nineteenth century, given the 'standards so different in origin' worked out by writers 'without reference to that body of international usage which always insensibly exerts its wholesome influence whenever particular rules are under consideration, there would be almost as many distinct codes as there are writers of authority'. ${ }^{2}$ Scholarship operated through doctrinal paradigms. Writers would 'seise on oracular pronouncements and reiterate them for generations'. Impressions would then emerge

in the minds of those same writers that the rule exists simply because they are writing about it as if it exists. The relevant practice is largely the opinions of earlier writers, salted with the occasional instances of supportive State behaviour that have come along. Instances of contrary behaviour are dismissed in footnotes as irrelevant to the consensual view of scholars, if they are acknowledged at all.

An example is provided by what Onuf called a putative rule on the three-mile limit of the territorial sea, adding that 'Scholars were shocked when a substantial number of States resisted codification of the three-mile limit at the Hague Codification Conference in 1930'. Then,

\footnotetext{
1 N Onuf, Global Law-Making and Legal Thought, in N Onuf (ed.), Law-Making in the Global Community (1982), 1 at 44.

2 WE Hall, A Treatise on International Law (1895), 2-3.
} 
with the bureaucratisation of foreign policy in the nineteenth century, diplomat-bureaucrats replaced writers as an integrative feature of the system, jurists began to replace writers as law-making catalysts and codification, which initially was a private affair, gradually became an inter-State exercise. Thus, 'As the 1930 Hague Conference eloquently testified, scholars found not only that they could no longer make oracular law but that the oracular pronouncements of earlier centuries were not nearly so much cherished by States as they were by successive generations of scholars'. ${ }^{3}$

Therefore, 'The chronic upheaval of the twentieth century has all but destroyed the credibility of the legal order invented by scholars ... Gone is the scholar's preeminent role in the articulation of a renewed legal order.' 4

Such privileged role of scholars was due to their privileged position in addressing the audience of those who taught, researched and practised international law, or were interested in it. This enabled scholars to present, or even re-invent, international law as they deemed it fit, as their philosophical, ethical, social or political convictions required. A scholar motivated by extra-legal considerations ran a greater risk of losing scholarly independence. Each generation of theorists was guided by principal theoretical categories adopted as the dominant trends of legal theory of their and preceding academic generations. Thus theory could both advance beyond the actual state of development of international law, and stay behind it. On the other hand, government legal advisers, whose role is to advance the viewpoint of a particular government, cannot always give an impartial view either. A practising lawyer can similarly be influenced by political, strategic, economic and ideological considerations, ending up asserting legal positions or attacking established legal positions to reinforce those considerations.

The relative demise of the role of scholars has been reflected in Oscar Schachter's articulation of the theme of an 'invisible college' of international lawyers. This 'invisible college' was not meant to justify subjectivism in legal reasoning and the substitution of agreement of States by a doctrinal judgment. The scholars' role was instead to ensure a representative expression of legal views that would be independent of views of particular governments, and bringing such independent legal expertise to the process of law-making, especially treaty-making. Lawyers not bound by views of a particular government could, even if having diverse views, form an objective legal judgment regarding international legal questions. ${ }^{5}$

The problem has thus invariably consisted in projecting, imagining or imitating the agency that can tell us what international law is and how it is supposed to work. The solution to this problem lies solely in understanding that there is not any one person specifically and distinctly suited to this task to the exclusion of anyone else. The real question is not 'who' but 'what',

3 Onuf in Onuf, 21-2; Gidel goes as far as to suggest that 'l'absence de possibilité d'accord sur la fixation à trois milles de la largeur de la mer territoriale démontre que la prétendue "règle des trois milles", si fréquemment mise en avant comme un axiome, ne saurait être considérée comme une règle de droit international maritime positif actuel"' La mer territoriale et la zone contigue, 48 RdC (1934) 133 at 138.

4 Onuf in Onuf, 44-5; the ILC then superseded the scholar: Onuf, 43. Obviously, Onuf's suggestion should be qualified to the extent that in many instances the ILC codification projects ended up as multilateral treaties widely adhered to by States. To the extent that these treaties apply, the need to examine State practice in detail does not arise. But this need persists where the relevant State has refused to accept a particular treaty.

5 O Schachter, The Invisible College of International Lawyers, 72 Northwestern University Law Review (1977-8), 217. 


\section{Research handbook on the theory and history of international law}

'how' and 'why'. These real questions relate to methods and evidence as opposed to the agency - methods that require considering international law as a body of rules consensually agreed by States, placing an emphasis on evidence as opposed to perception. The over-theorising of international law is due to projecting particular legal positions as desirable or necessary whenever they suit the particular agency's interests, goals, values and ideology. The only proper remedy against over-theorising is a focus on proper ways of identifying international law - the evidence that States have indeed agreed on a particular rule or principle as binding.

The proper study and analysis of international law should therefore aim at separating legal issues from those of morality, politics, ideology and social interest. Confusing socio-political factors - based on subjective appreciation - with the analysis of legal rules inevitably leads to ignoring the basic nature of international law as the body of rules agreed upon by States. It cannot be over-emphasised that, when agreeing on rules of international law through a treaty or custom, by that very agreement States manifest their judgement as to political, ideological and social considerations attendant to the operation of the agreed rule. Doctrinal attempts to assess or re-appraise agreed rules in the light of political, social and ideological factors essentially amount to attempts to replace the judgment of States embodied in agreed rules by the writers' own judgement. The actual value of particular theories thus depends on the degree of their reflection of the agreed content of international law. Critical and analytical theories can usefully explain various aspects of operation of the international legal system, and point to its social implications, drawbacks and options for improvement. Such theories are not, however, supposed to re-appraise, depending on the writers' political and ideological preferences, what the actual content of international law is; if they attempt doing so, they risk becoming theories for the sake of it, with little or no relevance to how the international legal system actually works.

The problem of non-law arises once international law is identified with consensually agreed positive law. ${ }^{6}$ States, as principal and primary entities in the international legal system, need certainty as to whether or not they are bound by a particular rule of international law. The line separating non-law and law is thus crucially significant. As shown, prior to the eighteenth century international law was mainly explained by immemorial custom, natural law and natural reason: these can acquire or consolidate their validity by virtue of States having either observed or not contradicted their existence and relevance, notably by falling short of adopting by agreement a contrary rule or practice. ${ }^{7}$ On that approach, even if there was no agreed rule of positive international law on a particular matter, natural law assertions as to fairness, propriety or reasonableness of particular solutions with regard to that matter could still be envisaged. By contrast, identifying international law with positive law, as we do today, means that, in the absence of a rule consented to and agreed upon by States, political, ethical or social considerations relating to the subject-matter of such possible or putative rule have no relevance within the international legal system.

In terms of the difference between established rules of law and aims of the legal system, Fitzmaurice has observed that law aims at ultimate justice, but achieves it indirectly, by methods the immediate object of which is 'not so much justice as such, but order, stability, certainty, and the elimination of that subjective element that cannot fail to enter into any attempt

6 See, on multiple aspects of the relationship between law and non-law, A Orakhelashvili, Interpretation of Acts and Rules in Public International Law (2008), chapters 5-8.

A D'Amato, What 'Counts' as Law? in Onuf (ed.), 83 at 98. 
to apply justice directly, and which often vitiates it'. Law is obeyed not because it is just but because it is unjust not to obey law. ${ }^{8}$ As Kelsen observes in a way similar to Fitzmaurice, goodness or badness of a particular behaviour depends on its compliance with the presupposed legal norm; the relevant value judgement can only relate to the conformity with that norm. For:

Without presupposing a general norm prescribing (or forbidding) something, we cannot make a value judgment in the objective sense of this term. The value attributed to an object is not given with the properties of this object without reference to a presupposed norm. The value is not inherent in the object judged as valuable, it is the relation of this object to a presupposed norm ... the question as to the highest value in the subjective sense of the term can be decided only emotionally, by the feelings or the wishes of the deciding subject. One subject may be led by his emotions to prefer personal freedom; another, social security; one, the welfare of the single individual; the other, the welfare of the whole nation. By no rational consideration can it be proved that the one is right or the other wrong. ${ }^{9}$

\section{THEORETICAL OPTIONS FOR DEMONSTRATING THE LEGAL CHARACTER OF INTERNATIONAL LAW}

Historically, two options have been deemed conceptually suitable to deal with the issue of international law in the society where, unlike national law, there is no government imposing law on legal persons: to link international law to natural law, or to deny its existence by reference to the nature of statehood and sovereignty. This dilemma had caught scholars and significantly impacted the range of intellectual choices they could adopt, and natural law emphasising inherency of the law to human societies was obviously used rather heavily. To illustrate, Sir Henry Maine has suggested that 'The greatest function of the Law of Nature was discharged in giving birth to modern International Law'. Grotius and his successors borrowed directly from the Romans the principle that jus gentium as a branch of natural law regulates relations between independent States which are not subject to any higher sovereign authority. ${ }^{10}$

Natural law is, on the other hand, a set of statements as to natural reason that could be used at the service of diverse agenda. Kelsen draws on Pufendorf's thesis that the law of nature can be identified by reference to the nature, condition and desires of human beings, but that men are often malicious, petulant and perverse and think that they can secure greater good from the violation than from the observance of law. ${ }^{11}$ The nature of man is not without relevance to policies independent States choose and activities they undertake. How then, Kelsen asks, could the law of nature be deduced from the nature of man? He clarifies:

It is not from the nature of man as it actually is that Pufendorf - and all other writers - deduce what they consider to be the natural law; it is from the nature of man as it should be, and as it would be if it would correspond to the natural law. It is not the law of nature which is deduced from the nature, the 
real nature, of man, it is the nature of man, an ideal nature of man, which is deduced from a natural law presupposed in some way or another. ${ }^{12}$

This produces an analytical dilemma, requiring identification of the ways that would explain the inherency of international law. One way is Kant's categorical imperative, requiring men to act in the way that one would like to see becoming universal law, and reinforcing the principle of the legal equality of States based on the reciprocity of rights and obligations. This has further been expressed in Vattel's Golden Rule of Sovereigns, which requires that States treat other States in the way they wish to be treated themselves. In other words, the key is not whether one wants to behave in a particular way but whether one wants to see the same conduct performed in relation to oneself. On the basis of reciprocity inherent to the categorical imperative, it is States who decide what they want to see done to them and who therefore give or withhold consent in relation to creating international legal rules. This refers not to reciprocity in terms of what States actually do to each other, but to reciprocity as a normative principle requiring that States do to others what they desire to be done to them. If this is taken as a premise, then Pufendorf's emphasis on desires and interests of States as the basis for natural law can be understood as the way that could reinforce the inherency of international law grounded on legal equality of States. International law can thus be seen as a legal system based on reciprocity and consent on the plane of relations between States.

John Austin denied that international law is law because it was not imposed upon States by a sovereign authority; some nineteenth-century scholars have insisted that international law is external public law of States (äusseres Staatsrecht). G-F von Martens adopted the view that this external public law was based on a pre-positive natural law which applies to State conduct before, as it were, the State enacts its positive laws. In relation to external relations with foreigners, a State as a legal person conserves its natural relations ('conserve son rapport naturel') to those who are not its members, whether other States, peoples or individuals. Therefore, natural law applies to the State's external relations (droit public exterieur). Such external public law is a branch of the law of nations. ${ }^{13}$ But if taken on its face value, 'external public law', of national origin yet relating to international affairs, also constitutes a doctrinal construct enabling the State to unilaterally project its political, strategic, economic or ideological visions as binding international law, or its replacement. The same applies to modern notions of 'foreign relations law', predominantly used in the United States, which covers some domestic law and some international law rules and practices. Precisely for that reason, it cannot be a discrete or homogenous body of law, because the basis of validity of any legal rule whatsoever has to be either national or international.

In the nineteenth century, Georg Jellinek suggested the theory of self-obligation (Selbstverpflichtung) to explain the binding force of international law. Jellinek's two initial options of analysis are either to logically deduce the existence of international law above and over States, or to establish its existence by referring to those legal concepts that are necessary for the existence of all law whether national or international. Jellinek specified the aim of his analysis as locating the existence of rules that inherently follow from the nature of international transactions. Jellinek further observes that the very nature and permissibility of treaties in international relations militated against viewing international law as external public

12 Kelsen, 487-8.

13 G-F Martens, Précis du droit des gens moderne de l'Europe (1831), 40. 
law of States (äusseres Staatsrecht). ${ }^{14}$ Jellinek's principal thesis, however, is that there can be not merely State will but such State will that can bind the State; States can arguably bind themselves in the sense that the one who obliges is identical with the one who is obliged. In order to establish this, Jellinek considers it necessary first to prove that the State can bind itself in its own legal system towards private legal entities. If the State can subject itself to itself, then it can also set the law internationally ('wenn er sich sich selbst unterordnen kann, ist er im Stande, sich ein Recht nach Aussen zu setzen'). ${ }^{15}$ However, that does not explain away the fact that the first type of self-obliging or self-binding takes place within the State's domestic legal order, and the other on the international plane. One is simply inadequate to rationalise the other.

But Jellinek still accepted that the ultimate basis of international law, even if 'self-obliged' by States, stems from the necessities of inter-State relations, and he recognised that treaties cannot have legal effect in the absence of legal rules that stand above treaties and from which treaties obtain their legal validity. ${ }^{16}$ This anticipated the argument of Brierly and Anzilotti regarding the fundamental and non-consensual rule from which treaties derive their legal force, thereby underlining the importance of this factor for scholarly legal thought across different theoretical quarters.

Jellinek alluded to Kant in stating that being bound by a treaty is based on the categorical imperative, which is seen as an indication that States see themselves as bound. ${ }^{17}$ Still, Jellinek's further effort to prove that States can bind themselves internationally is not that straightforward. One option is to suggest that the domestic law of obligations can be applied by analogy to the process of international treaty-making and constitute part of jus gentium in the way it was understood in Roman law, among others as part of naturalis ratio. But this option stumbles at the difficulty of making analogies with principles that do not form part of the same legal system. ${ }^{18}$ Then Jellinek demonstrates the existence of international law by reference to the obvious facts that States continue to agree internationally with each other and regard these agreements as binding, as has been manifested in the 1871 London Protocol. ${ }^{19}$ This emphasises the relevance of agreement as the basis of international law, in line with the classical consensual positivist tradition.

Jellinek's analysis illustrates how the intellectual tradition of international law of his day was caught between the pressures of visions of power politics as ultimately determinative of the outcome of legal claims, and the extreme theories of denial of international law. Jellinek seemed to identify as his principal task rationalising the binding force of international law through the use of intellectual categories that would be acceptable to the audience whose thinking was shaped by the nineteenth-century German scholarship of international law, as opposed to demonstrating the essence of international law in a way that would have a durable scientific value.

In England the above dilemma produced the theory of the denial of international law advocated by John Austin. This intellectual platform is to some extent curious because it relies on

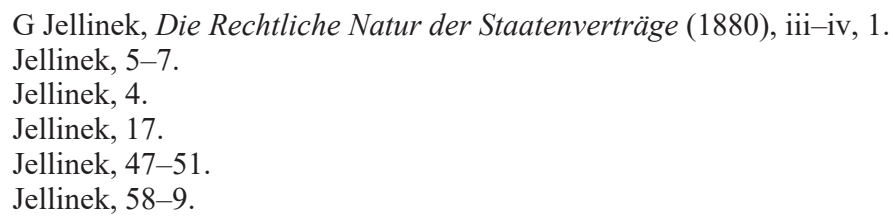


only part of the intellectual heritage that was available at that time: it is compatible with the vision of Hobbes, who, in the absence of an international government, denies that international law is law, and with that of Pufendorf, who admits the existence of international law but only as natural law, because positive international law allegedly cannot exist for the very same reasons as are emphasised by Hobbes. This platform does not consider the tradition of Grotius, Wolff and Vattel - who apply the idea of law to inter-State relations - later to be voiced in the writings of JL Brierly and Hersch Lauterpacht.

The principal discrepancy in Austin's reasoning relates to his identification of the nature of positive law with the need for structural subordination through commands between the law-maker and entities to which that law applies. ${ }^{20}$ It is however difficult to see how the positiveness of law - that is, its postulation in an externally intelligible manner to repeatedly apply to facts covered by its content - is inherently constrained to the element of subordination to commands issued by a sovereign. According to Fitzmaurice, the problem of the ultimate foundation of the binding character of law is in no way peculiar to international law. It is a general legal problem, and arises just as much with regard to national law as it does for international law. Fitzmaurice's reasoning on that point is worth pursuing at some length:

A man is told he cannot ride a bicycle along a certain footpath. He asks why, and is told because it is forbidden by a certain by-law. He asks what is the authority for the by-law, and is told that it is made under an Act of Parliament. But if he asks what is the authority for the Act of Parliament, and what is the source of the rule that Acts of Parliament have the force of law, there is, and can be, no final answer. As Salmond says, no Statute can confer this authority on Parliament, for that would be to assume the power that has to be accounted for. Whence would that Statute itself derive its validity? No doubt the legal force of Acts of Parliament derives from the Constitution, written or unwritten. But then it must be asked what is it that gives the Constitution legal force? In some countries the Constitution has itself been enacted: but what gave that enactment validity? If those who enacted it had the legal as distinct merely from the physical, power to do so, whence did they derive it, what is the rule of law that conferred the power on them, and whence did it derive its validity? And so on. Ultimately there can be no answer, or there can only be a series of answers, no one of which can be absolutely final. The reason why the difficulty is less obtrusive in the national than in the international field, is that in the national field the interim terms in the series afford a sufficiently satisfying practical basis for the obligatory force of the law to make the average person feel it unnecessary to go further - for instance, it is usually enough that the law has been enacted by the proper method, without inquiring what it is that confers legal force on enactment by that particular method. In the international field, however, there are no interim terms of quite the same kind. The absence of any patent and obvious source of obligation, such as might exist if there were an international legislature, deprives the international jurist of any manifest point at which he can rest, and which he can regard as a satisfactory terminal point beyond which there is no practical necessity to go. ${ }^{21}$

The difference between national and international legal reasoning is thus merely a difference in (the lack of) established clichés. The difference between legal orders is then no more than, as Brierly called it, that of social organisation. Whether a legal system can exist or operate within the particular community is not necessarily contingent on whether that community also adopts a particular form of social or political organisation.

20 J Austin, The Province of Jurisprudence Determined (1954), 141-2, 201-2.

21 G Fitzmaurice, The Foundations of the Authority of International Law and the Problem of Enforcement, 19 Modern Law Review (1956), 1 at 9-10. 
JB Scott engaged with Austin's argument by pointing out that 'a violation of rights under the treaty would lead to a "command" from the injured State to the State guilty of the infraction'.22 This command would be enforced not by a public authority but by public opinion. By analogy to English criminal law, Scott argued that the evil threatened is not necessarily imprisonment but social ostracism, which is in the end responsible for many individuals refraining from committing a crime. ${ }^{23}$ The feasibility of this approach within the international legal system would stumble at major hurdles. The international legal system operates on the basis of the consensual imperative and is thus inherently pluralistic. It is difficult to find any indication of an overwhelming social opinion that would be accepted in the same way by States adhering to diverse political and economic systems. Moreover, social opinion is at times played against the law with a view of imitating an alternative to the existing legal position. One example of this relates to claims of 'humanitarian intervention'. The NATO attack on the Federal Republic of Yugoslavia (FRY) in 1999 commanded substantial socio-political support, but its legality has been rejected by the world at large, as demonstrated by the position expressed by the overwhelming majority of States. ${ }^{24}$ An emphasis on social opinion and social ostracism actually imitates alternatives to consensual explanation of international law. The explanation of the basis of international law has instead to fit with the decentralised inter-State nature of the international legal system, allowing no possibility of States being bound without their consent.

It does not seem that Austin's intention was to identify the legitimacy of national legal systems with the physical power of governments to coerce individuals. The same applies essentially to HLA Hart's emphasis on 'secondary' rules. ${ }^{25}$ Hart made no genuine effort to identify whether international law included those 'secondary' rules that determine how law is produced, interpreted or amended. As it happens, it does include them in abundance. The rules on law-making, law of treaties and law of State responsibility constitute a firm and predictable background against which substantive international legal rules can be created, interpreted, implemented and modified.

All this demonstrates that 'structural' objections to the legal character of international law, although routinely given attention in textbooks, are essentially irrelevant. The principal - and more acute - theoretical question relates to the substantive aspect of the legal character of international law, that is, to its ability to consistently, predictably and indiscriminately apply to facts that its rules cover by their content. The substantive difference between international and national law has partly been projected by reliance on the structural difference between national and international law. The perception that the validity of international law differs from that of national law was articulated by thinkers as early as Bentham, who claimed that 'a treaty between two nations is an obligation which cannot possess the same force as a contract between two individuals'. Custom and treaty in inter-State relations could thus be denoted as law only 'by extending the meaning of the term, and by metaphor', for the organisation on

\footnotetext{
22 JB Scott, The Legal Nature of International Law, 1 AJIL (1907), 831 at 837.

23 Scott, 831 at 844 .

${ }^{24}$ Cf. Statement by the Non-Aligned States (132 States), 24 September 1999, in I Brownlie, Principles of Public International Law (2008), 744; Statement by the Rio Group, Letter dated 26 March 1999 from the Permanent Representative of Mexico to the United Nations addressed to the Secretary-General, A/53/884, S/1999/347, 2; see also S/PV.3988, 23 March 1999 for the positions of India and China.
}

25 HLA Hart, Concept of Law (1961), 209 
which they were premised was defective and incomplete. ${ }^{26}$ Therefore, unless the legal nature of international law is located in its substantive as opposed to its structural aspect, its binding force cannot be explained at all and Austin's objections to the legal character of international law become insurmountable.

The legal character of international law cannot thus be explained by factors external to the overall nature of law. International law's being grounded in the agreement between States must be good enough to explain the validity and legal character of this legal system, for this approach essentially focuses on the inherent value of the expression of will and agreement of States. This approach is premised on the inherency of international law in inter-State relations to enable States to properly conduct their business, but it also stresses that, being inherent in that way, international law is also consensual. Its consensual nature is, in the end, the rationale for its inherency. As Fitzmaurice observed: 'If law is necessary, that necessity must lie precisely in the need for obligatory rules as between members of a society, and it would involve an inherent contradiction to propound law as necessary, if it was not also necessarily binding. ${ }^{27}$

The above Benthamite perception of international law being less law due to its structural background was widely held by international law scholars over a long period of time, until the fallacy of this myth was exposed within the positivist scholarship of JL Brierly and Hersch Lauterpacht. ${ }^{28}$ Lauterpacht warned against identifying the conception of law exclusively with more 'developed' legal systems, and provided a consistent doctrinal approach demonstrating the full-fledged legal character of international law through the thesis of completeness and effectiveness of international legal regulation. Lauterpacht's core argument is that international law may be structurally different but it is no less a system of positive law than national law is, and, regardless of its stateless nature, it possesses tools which it robustly uses through the process of interpretation and adjudication to enable the international legal system to provide answers to contentious questions and controversies. ${ }^{29}$ Lauterpacht never tried to re-appraise or re-invent the fundamentals of international law; he took international law as he found it. The distinctive impact of his scholarship is that he discerned and identified the pertinent elements of this legal system in a more complex way, and thus better, than many other preceding or contemporary scholars.

Brierly's remedy against the absence of centralised law-making and law-enforcement machinery is to appeal to extra-consensual factors for addressing the issue of imperfection and incompleteness of international law. It was true that a new rule of international law cannot be imposed on a dissentient State by any process compatible to the legislative act which imposes a rule of law on a dissentient individual within the State. But this was a difference merely of social organisation. ${ }^{30}$ Brierly's analysis also emphasises the extra-consensual principle of pacta sunt servanda as the inherent extra-consensual rule that validates the essence and binding force of international law as consensually agreed rules. If such extra-consensual rule was lacking, the consensually agreed international law would also lack binding force. This

Quoted in Scott, 831 at 834.

Fitzmaurice, 11 (emphasis original).

On which see, in general, Orakhelashvili (2008), chapter 1.

H Lauterpacht, The Function of Law in the International Community (1933), 433; for analysis see Orakhelashvili (2008), chapter 1.

30 JL Brierly, The Basis of Obligation in International Law (1958), 10-14, 16-17. 
way, the consensual tool of law-making has constitutional significance, and legal positivism is further emancipated and consolidated to rationalise the essence and workings of international law as the system of positive legal rules. How else could one rationalise the inherency of international law in the society of States which is pluralistic and hence divided along with the political and ideological differences between States, there being no ideology common to the entire world, no generally accepted socio-ideological basis on which the goodness or badness of States and their conduct could as such be determined? And thus, the consensual foundation of international law is necessarily premised on the sameness of the legal capacity of States.

\section{NATURAL LAW AND POSITIVE LAW}

If, as demonstrated, international law is a body of consensually agreed rules, the relevance of natural law can be examined only against that background. Natural law may be unpopular in some quarters, which may also serve as a deterrent to its doctrinal use. But, as Kelsen observed, 'The reason why the natural-law doctrine, in spite of its obvious fallacies, has had, and probably always will have, great influence on social thinking is that it satisfies a deeply rooted need of the human mind, the need for justification'. ${ }^{31}$

The words 'always will have' attest to the timeless relevance of this problem. While in older writings the natural law terminology was used in an express manner, the range of other theories has embraced natural law thinking in a quieter way. Hence, the natural law approach is represented in international law writings in a more widespread manner than the semantics ordinarily used to describe it would suggest on its face. On jurisprudential terms, any articulation of ethical or socio-political preference is bound to represent the reasoning based on natural law, that is, law that is not derived from the will of constitutionally established human authority, which in the case of international law is the consent given by States. Any articulation of policy that is desired to be part of law but is not yet part of it, any propagation of what ought to be law or what has to be treated, in discourse or practice, as part of law even if positive law has not embraced it, invariably and inevitably forms part of the natural law tradition.

The doctrinal understanding of positivism varies according to a theoretical framework: it can refer to the importance of sanctions, or to the Austinian 'command' theory. But objections to positivism do not vanish once the Austinian hurdle is cleared. Instead, the very idea of the law that is laid down through the sources of law only, posited as it were, often amounts to a political and ideological problem that does not easily allow itself to be blended away or finetuned. To illustrate, D'Amato describes the essence of positivism in existential, and prejudicial, terms, claiming that 'a legal positivist believes that a rule is or is not a rule of law, and if it is a rule of law, then what it commands, however absurdly, gives rise to a legal obligation'. In this context, D'Amato links the positivist-naturalist dichotomy to the problem of interpretation. A court believing in naturalism would correct a meaningless provision in a statute, while a 'positivist' court would enforce the statute as it stands, as only the legislature can 'remedy the mischief'. Such a 'pragmatic' approach specifies that the naturalist is a human interpreter of law; law is not as much an aim for itself but a means towards the attainment of human ends. Natural law, according to D'Amato, combines two great substantive principles: survival of the

31 Kelsen, 481 at 501. 
human race and justice to individuals. Any artificial entity, such as a State, standing in the way of the attainment of these goals is contrary to natural law. ${ }^{32}$ But this approach does not clarify who determines what the 'human ends' in question are; these 'human ends' can be seen as a policy-oriented Grundnorm to deny the consensual foundations of international law.

This approach construes naturalism as referring to anything that is not positive law, including political, social and ideological considerations. Natural law has been used, expressly or impliedly, to describe anything that opposes consensual positivism - from George Scelle's social interest theory to the New Haven policy-oriented school. But this is a perverted meaning of naturalism. Its narrower, more genuine and legitimate meaning which has been accepted as part of the international legal discourse focuses not on interests, policies or ideologies, or on State preferences of any kind or solutions sought with regard to international problems, but on elements that are inherent to the legal system of international law; it is not about using extra-legal, above all political, argument to adversely affect the legal reasoning and justify deviation from positive law, but instead aims to clarify the basis of that very legal argument by focusing on fundamentals of the relevant legal system, helping the system of positive law to work as a system, tying its loose ends, as it were. But even in that sense, the bulk of these natural law principles have already been reflected in positive international law. ${ }^{33}$

Confusion could also ensue if seeking to identify 'standards of review' of positive laws on the basis of natural law. What is the threshold warranting the intervention of natural law? Should the 'reviewable' positive law be meaningless, unworkable, immoral, unethical, self-contradictory, undesirable, unsound, or merely something that could be improved? Writers adhering to such broad 'remedial' and interventionist doctrines of natural law have not provided a clear answer to this question.

\section{DEVELOPMENT OF THE NATURAL LAW THEORY}

Ius gentium derives from natural law as established by the natural reason among all nations. While the notion of jus gentium originated with the Roman legal tradition, Sir Henry Maine thought there was no evidence adduced or passage cited to show that Roman jurisconsults believed that natural law applied to relations between States. ${ }^{34}$ To illustrate this natural reason with regard to inter-State relations, Vitoria has referred to whatever is widely practised by all nations, such as treating strangers humanely. At the beginning of the world, when all things were held in common, everyone was allowed to visit and travel through any land, which intercourse was not intended to be suppressed through the establishment of national boundaries. ${ }^{35}$ As explained, Vitoria took the conception of ius gentium from the Roman jurisprudence and applied it to the relations of peoples. International law was the body of rules which natural reason had established between all nations. However, natural law is now associated not with human nature but with the rules allegedly established by nature to deal with relations between

\footnotetext{
32 D'Amato, 88-91; and see below Chapter 11 for illustration of the connection between natural law and New Haven policy-oriented doctrines.

33 See for detail of such aspects of natural law, Orakhelashvili (2008), chapter 3.

34 Maine, 102.

35 F de Vitoria, De Indis, in A Pagden and J Lawrence, Francisco de Vitoria - Political Writings (1991), 278.
} 
nations (inter omnes gentes). This constituted a fundamental departure from older versions of natural law. 'Ius gentium' means the law of nations; 'ius inter gentes' means the law between nations; international society is then a societas naturalis gentium. This implies a recognition, at the same time, of the independence and of the interdependence of States, and of their reciprocal rights and obligations. It points to the existence of a juridical tie between nations, which constitute an international society; to the inherency of international law to international society along the lines with the maxim ubi societas ibi ius. This interdependence then entails limits on the sovereign powers of States. The underlying philosophy is the same as that of the transition from the 'state of nature' to the 'social contract'. The formation of national groups on more clearly defined territories does not imply the intention of these nations to suppress all intercourse natural to men; the 'rights' incidental to the state of nature are thus preserved and perpetuated. ${ }^{36}$

Vitoria reasons from the viewpoint of universality in explaining why Spaniards can travel to the countries of native Indians. As 'it would not be lawful for the French to prohibit Spaniards from travelling or even living in France, so long as it caused no sort of harm themselves; therefore it is not lawful for barbarians either'. Similarly, 'barbarians themselves admit all sorts of other barbarians from elsewhere, and would therefore do wrong if they did not admit Spaniards'. Barbarians cannot prohibit Christians to trade with them any more than Christians can do that to other Christians. All that would be against natural and divine law. A human enactment (lex) to that effect would also contradict natural law, and on that account be inhumane, unreasonable and without force of law. ${ }^{37}$ This illustrates an early statement of natural law as the body of principles that controls, in toto, the substance that positive law can permissibly and validly have. Such substantive view of natural law sees it as shadowing the process of positive law-making. At the same time, Vitoria opposes any cultural or religious exclusivity to impact any legal position, and subscribes to the universality of international law, by way of articulating an early version of natural law as the basis of international law, if the latter is to apply to inter-State relations.

Suarez drew a clear distinction between natural law and ius gentium. Natural law is based on the necessity following solely from the nature of the case, while ius gentium derives from some other source. Ius gentium does not prohibit things because they are evil, but renders them evil by prohibiting them. Ius gentium is therefore positive and human. ${ }^{38}$ This mirrors the modern distinction between natural law and positive law.

However, Suarez then distinguishes between natural law and ius gentium in the way that the latter 'came into existence not through [natural] evidence but through probable inferences and the common judgment of mankind'. ${ }^{39}$ It is not immediately clear whether this is the same common judgement of mankind that has to acknowledge the content of natural law. What is clear, however, is that with Suarez the distinction between natural law and law applicable to relations between States is rather relative. But the separation of the inter-State realm from

\footnotetext{
36 C Phillipson, Franciscus a Victoria (1480-1546): International Law and War, 15 Journal of the Society of Comparative Legislation (1917), 175 at 180-1

37 Vitoria, 278-80.

38 F Suarez, De legibus, ac deo legislatore (1612), in G Williams et al., Selections from Three Works of F Suarez (Volume ii, 1944), 342, 344.

39 Suarez, 344
} 
the global transnational realm in which natural law or jus gentium is initially engendered is certainly clearer.

Even the communication between States in practice would witness reliance on natural law. In 1753 the British government, in a communication to the Prussian government, specified that 'The Law of Nations [is] founded upon justice, equity, convenience, and the reason of the thing, and confirmed by long usage'. ${ }^{40}$ This is similar to the approach of Pufendorf in that the natural reason is the basis of international law, further reflected in the long usage. ${ }^{41}$ There is no obvious emphasis on State consent. It is noteworthy that this position is expressed in the historical period that is widely considered to have been dominated by nationalism, sovereignty and tradition of the raison d'Etat.

The premise inevitably underlying the British statement is that there is such 'justice, equity, convenience, and the reason of the thing', upon which Britain is relying, and which at the same time will be intelligible and acceptable for Prussia. Much as natural law is conceptually derived from a transcendent reason and justice, in the context of the international system it necessarily requires reliance on such principles of reason and justice as will be both objectively intelligible to States that have different national interest and political traditions, and also such as to be subjectively understood by those States as constituting the basis of reason and justice that underlies natural law. As is clear from Vitoria's reasoning, the natural law of nations is the one that suits the nature of the inter-State society; but then it has to be the natural law that States understand and acknowledge in their mutual intercourse, in relation to which they have a shared understanding, not one that is deduced by a writer from a transcendent reason.

One way of comprehending natural law from this perspective might be to focus on principles underlying multiple national legal systems, such as those which partly reinforce the concept of 'general principles of law' under Article 38(1)(c) of the International Court's Statute. If States accept and apply the principles in question in their own legal systems, they thus recognise that these are just and reasonable. This in fact sounds similar to Jellinek's 'self-obligation' argument that referred to States binding themselves, towards private entities, in their own national legal systems. As FA Mann has pointed out, a principle is a general one if it is being applied by most representative systems of municipal law; the general principles are determined and defined by comparative law. ${ }^{42}$ FA Mann further develops the notion of a commercial law of nations that can arguably be explained partly by transnational natural law as articulated by Lord Asquith, and partly as a modern version of jus gentium as it was known in ancient Rome. ${ }^{43}$

But this approach leaves two questions unresolved. In the material sense, principles accepted in domestic legal systems may not always be indicative of what the international legal position is. In the formal sense, 'general principles of law' include not only principles accepted in foro domestico but also those that relate to the international system and inter-State relations. This, then, transfers the whole reasoning from the area of justice and reasonableness into that of evidence, and requires reference to and understanding of the attitudes of States in their mutual relations. The principal tools with which international law is familiar in this sense are State practice whereby States act and react, and opinio juris whereby States manifest their

\footnotetext{
40 R Phillimore, Commentaries upon International Law (I 1879), 15.

41 See below Chapter 4.

42 FA Mann, Reflections on a Commercial Law of Nations, 33 BYIL (1957), 20 at 36-8.

43 Mann (1957), 40
} 
positions as to the legality or illegality of particular acts or practices. Once, then, the natural law reasoning is moved into the area of evidence, it would stumble at the fact that there is no tool to infer the judgment of States as to the propriety, justice and legitimacy of particular rules, acts and practices other than State practice and opinio juris, which constitute the basis of customary international law. In relations between States, imagining tools alternative to those that express agreement between them is simply not feasible.

From here, the reasoning can be conducted by asking two questions. In the first place: is natural law simply another version of customary law? In the second place: how necessary is the requirement of opinio juris for the formation of customary law, and, if it is, what does it reflect and embody - agreement between States or merely the acknowledgement by States of some inherent natural justice and reason? To answer these questions, the precise essence of opinio juris as part of custom-generation must be identified. And, of all the theories that deal with opinio juris, the one rationalising it as State consent and agreement is most plausible. ${ }^{44}$

The above discrete problems with reconciling the idea of natural law with international law are corroborated by a broader conceptual problem inherently hidden in the very essence of natural law reasoning. As Kelsen specifies, if "natural law is considered to be a system of substantive rules, not a formalistic authorization of any positive law, then the contradiction between a human nature from which this natural law is deduced and a human nature which makes positive law necessary is inevitable' ${ }^{45}$

The relationship between natural law and positive law has long been handled by the international law doctrine. Inter-State relations are, according to Phillimore, governed

partly by Divine, and partly by positive law. Divine Law is either (1) that which is written by the finger of God on the heart of man, when it is called Natural Law; or (2) that which has been miraculously made known to him, when it is called revealed, or Christian law.

Furthermore, 'it is of great practical importance to mark the subordination of the law derived from the consent of States to the law derived from God' ${ }^{46}$ Phillimore used his natural law approach to justify the universality of international law and to demonstrate that international law applied both to European and non-European world:

whenever communities come into contact with each other, before usage or custom has ripened into a quasi contract, and before positive compacts have sprung up between them, their intercourse is subject to a Law ... if the precepts of Natural Law are obligatory upon Heathen States in their intercourse with each other, much more are they binding upon Christian Governments in their intercourse with Heathen States. ${ }^{47}$

Even more pertinently, it was 'clear that the occasional vicious practice cannot affect the reality of the permanent duty'. ${ }^{48}$ Furthermore, natural law sets limits to positive law-making:

\footnotetext{
44 See for detailed analysis and critique of all relevant theories, A Orakhelashvili, Natural Law and Customary Law, 69 Zä̈RV (2008), 61-100.

45 Kelsen, 486.

46 Phillimore, Commentaries upon International Law I (1879), 15.

47 Phillimore, I, 20-2.

48 Phillimore, I, 23.
} 
the Law derived from the consent of Christian States is restricted in its operation by the Divine Law; and just as it is not morally competent to any individual State to make laws which are at variance with the law of God, whether natural or revealed, so neither is it morally competent to any assemblage of States to make treaties or adopt customs which contravene that Law. Positive Law, whether National or International, being only declaratory, may add to, but cannot take from the prohibitions of Divine Law. ${ }^{49}$

WE Hall posed the question whether there is 'an absolute right, applicable to human relations', whether deriving from the law of God or 'law of nature inductively reached', or 'erected metaphysically'. ${ }^{50}$ States, however, are independent beings, subject to no superior 'person or body of persons exists to whom authority has been delegated to declare law for the common good; a state is only bound by rules to which it feels itself obliged in conscience after reasonable examination to submit'. A transcendent absolute right 'can only be a source of confusion and mischief when it is regarded as a test of the legal value of existing practices'. ${ }^{51}$

Having ascertained that much, Hall then proceeds to examine the nature of 'usages' which constitute international law, and observes that

A large part of international usage gives effect to principles which represent facts of state existence, essential under the conditions of modern civilised state life. ... Another portion of international usage gives effect to certain moral obligations, which are recognised as being the source of legal rules with the same unanimity as marks opinion with respect to the facts of state existence. No third basis of legislation can be found of such solid value as are the essential facts of existence of a society and the moral principles to which that society feels itself obliged to give legal effect. Of both the foregoing kinds of usage, therefore, it can be affirmed unhesitatingly that they possess a much higher authority than any other part of international law. ${ }^{52}$

This sounds like a postulation of the 'absolute right' which Hall has just rejected, and moreover the attribution to that 'absolute right' of a greater normative force than positive law can possess. Hall therefore rejects natural law in a principled sense, but essentially offers a covert natural law reasoning ridden by socio-ideological underpinnings that the author in question professes and upholds. Hall is not a positivist, as his reasoning consistently avoids an emphasis on consent, agreement of States; instead of custom he speaks of 'usage' expressing the pre-existing superior principles.

While both Hall and Phillimore profess that the natural law reasoning can influence the state of positive law, none of them go as far, expressly at least, as Lorimer in advocating the role of doctrine in shaping the content and legal force of international law. Lorimer refers to 'the branch of positive law which we call the law of nations', but then asserts that 'the law of nations is the law of nature, realised in the relations of separate political communities' ${ }^{53}$ Given that enforcing international law in the absence of a central government and judiciary involves difficulties,

Natural law, in this, as in the other departments of positive law, would then retreat into the arsenal or the armoury of jurisprudence, and the jurist would not be called upon to wield it in his daily work,

49 Phillimore, I, 26.

50 WE Hall, A Treatise on International Law (1895), 2-3.

51 Hall, 4-5.

52 Hall, 6.

53 J Lorimer, The Institutes of the Law of Nations (1883), volume I, 19. 
but only when, in the higher capacity of a scientific discoverer, he sought to indicate what was amiss, or as a legislator to supply what was defective in the positive system which it was his business to expound, to administer, or to reform.

But the case is very different where the object of the law is itself indefinite or disputed, where its general doctrines have as yet no fixed and recognised meaning, and where the questions which arise are not questions of means but questions of ends. Here, unless practice be contented to wait indefinitely on the terrible and often unintelligible teaching of experience, it must still invoke the aid of theory: the positive international jurist has no firm standing-ground of his own: there is no progressive or consistent history to record, and the day for dogmatism has not yet arrived.

These considerations explain to us the exceptional dependence of the law of nations on the law of nature. In dealing with the law of nations, the jurist has always a preliminary function to perform, and as it is natural law that determines the objects of positive law in all its departments, the function is one which he can perform only by keeping it steadily in view. ${ }^{54}$

International law is thus presented as an underdeveloped legal system where the proper use of the evidentiary legal method has to be deemed unhelpful. The doctrinally projected indeterminacy of the actual legal position has then, according to Lorimer, to be remedied through ideological inputs. Consequently, according to Lorimer, there can 'be little question of the justice of the opinion which regards the law of nations rather as a branch of scientific inquiry than as a discovered system, or of the prudence of the academical arrangement which maintains its connection with natural law'. ${ }^{55}$ Lorimer's 'natural law' has no revealed or demonstrated systemic dimension - it is instead a product of the writer's subjective appreciation and of what he perceives as mainstream political ideology. This essentially amounts to a denial of international law as a system of positive rules and insistence of the relevance of ideology coated as 'natural law' to explain the rights and obligations of States.

This approach is further reflected in Lorimer's treatment of sources of international law. Customary law would matter only if consistent with the doctrinally projected natural law. ${ }^{56}$ Therefore, Lorimer asserts that 'There is no direction in which it is more necessary that we should keep the subjective channel to natural law distinctly before us than when we are called upon to distinguish between good and bad customs, because customs themselves claim to be objective witnesses to the very law by which their qualities must be tested. ${ }^{57}$

Permanent laws of human nature have predominant importance, and 'a custom, or a treaty, which is at variance with these laws, offers no contribution to the positive law of nations in the absolute or scientific sense' ${ }^{58}$ Ideological, social, political views ultimately constitute criteria against which the relevance and propriety of international law should be judged, and those rules of international law which are at variance with those theory-imposed criteria - albeit being based on proper sources of international law - have to be treated as irrelevant. The outcome is thus that the sources of positive law do not contribute much to the meaning and content of positive law, and consistently a theorist could arrogate to himself a power to declare the relevant positive law as irrelevant, or redefine it in terms of social, political or ideological premises which he represents.

\footnotetext{
Lorimer, I, 21-2.

Lorimer, I, 26.

Lorimer, I, 32-4.

Lorimer, I, 34-5.

Lorimer I, 54-5.
} 
Similar natural law propensities occur in the writings of Westlake. ${ }^{59}$ Westlake considers that reason is a source of international law, and directs the application of established rules of international law by reference to 'a sound view of the necessities of international life'. ${ }^{60} \mathrm{On}$ that account, States could hardly expect to be bound by what they have consented to.

The idea of positive law reflecting natural or generally binding law also put forward by JC Bluntschli. When civilised States assemble at international congresses, they intend not to enact treaty law that binds its signatories, but general legal norms, above all for the European world to be respected by all European States. They do not wish to create voluntary law (Willkürrecht) but to acknowledge the necessary law (notwendiges Recht) that is grounded in the nature of legal relations and in duties of civilised nations towards the humanity as a whole ('... ein notwendiges Recht anerkennen, welches in der Natur der Verhältnisse und in den Pflichten der civilisirten Völker gegen die Menschheit seine eigene Begründung hat'). ${ }^{61}$

The perusal of doctrinal views thus expresses the insoluble contradiction between the consensual positivist background of international law and such version of natural law as imagines substantive legal regulation shadowing, replacing or prevailing upon the rules and principles of consensually agreed positive law. Kelsen has therefore got it absolutely right: 'That the natural-law doctrine, as it pretends, is able to determine in an objective way what is just, is a lie'. ${ }^{62}$ Development of international legal theory has demonstrated that rejection of natural law and emancipation of positive law has hardly been a straightforward process. ${ }^{63}$ Positivism that emphasised the priority of neutral rules regulating State conduct regardless of States' preferences was not the dominant language of international legal scholarship before the early twentieth century, when positivist scholars such as Oppenheim, Anzilotti, Kelsen and Lauterpacht consolidated positivist treatment of international law and exposed the systemic dimension thereof. The key implication of this emancipation of positivism means that presenting the international legal system merely as the setting for articulating multiple political or ethical claims and positions is unsound and unrealistic. Political opportunism could go some way in shaping the claims and positions of governments and their advisers, but the system of positive international law operates a robust process of consent, interpretation and adjudication through which such political claims are screened, evaluated and recycled. The only feasible way of theorising the international legal system is consensual positivism.

\footnotetext{
59 Who has been described as a positivist: A Anghie, Imperialism, Sovereignty and the Making of International Law (2005), 40.

60 J Westlake, International Law, Part I (1910), 14-15.

61 J-C Bluntschli, Das moderne Völkerrecht der civilisirten Staaten (1868), 4-5.

62 Kelsen, 513.

63 See, in addition, Chapter 4 below.
} 